\title{
YEM VE YEM HAMMADDELERINDE BULUNAN OLUMSUZLUK FAKTÖRLERI VE HAYVANLARA YONELIK ETKILERI: 1: ORGANIK NITELTKLI OLUMSUZLUK FAKTÖRLERI
}

\author{
Sezai Kaya*
}

Hidayet Yavuz**

\section{Some unfavourable factors occuring in feeds and feedstuffs and their effects on animals. 1 : Organic unfavourable factors in feedstuffs}

Summary: In this article, various organic unfavourable factors ocauring in feeds ane feedstuffs and their effects on animals were reviewed. Unfavourable factors in feeds and feedstuffs occur as natural constituents of these substances or as formed during processing or contaminants of them. According to, these substances that are in the feeds and feedstuffs and have detrimental effects on animal growth were classified briefli as follows: cyanogenetic glycosides, phenolic substances, nitrates and nitrites, alcaloides, substances interfering with the utilization or activity of vitamins and proteins, oestrogenic substances, environmental and feedingstuff pollutants such as pesticides and industrial substances, mycotoxins and some substances added to feeds.

Özet: Bu makalede, yem ve yem hammaddelerinde bulunan genellikle organik yapidaki cessitli olumsuzluk faklörleri ve bunların hayvanlara yönelik etkileri incelendi. Yem vo yem hammaddelerinde bulunan seşilli olumsuzluk faktörleri bunlarn doğal olarak yapularında bulunabilecekleri gibi, hazurlanmalarn veya işlenmeleri szrasinda oluşabilirler veya gevre kirliliğinin bir sonucu da olabilirler. Buna göre, yem ve yem hammaddelerinde karsalaşlan ve hayvanlarin gelisnmesi veya yemlerin değerlendirilmesini bozabilen olumsuzluk faktörleri başlica siyanogenetik glikozidler, fenolik bileşikler, nitrat ve nitritler, alkaloidler, vitaminlerin kullanım veya etkinliğini ve proteinlerin sindirimini bozabilen

* Prof. Dic, A. ̈. Vet. Fak. Farmakoloji ve Toksikoloji Anabilim Dal.. ANKARA.

** Doç. Dr., A.Ü. Vet. Fak. Farmakoloji ve Toksikoloji Anabilim Dal. ANKARA. 
maddeler, pestisidler ve endüstriyel maddeler gibi çeire kirleticileri, yem ve vem hammaddclerinin hazzrlanması ve üretimi tekniklerindin ileri gclen sakmcular, yemlere katılan bazl maddeler ve mikotoksinler seklinde sinflandirlabilirler.

\section{Giriş}

Hayvancılıkta yapılan tün uğraşın. amacı yapılan birim harcamaya karşlık birim baş veya hayvan grubundan sağlanacak verimiı artırılmasına yönclik olmaktadır. Bu ise bir yandan yüksek verimli/ nitclikli hayvan irklarmun kullanılmasına, bir yandan da iyi bakım ve beslenmeyc bağımlılık gösterir. lyi bir yemlemenin yapılması isc kullanilan yem veya yem hammaddelerinin rasyonda yeterli ve dengeli olarak bulunması ve hijyenik durumlarının da iyi olması ile başarılabilmektedir.

Son. yillarda hayvancilıta uygulanan yoğun bakım ve beslenme programları, özcllikle kanath yetiştiriciliğinde olmak üzere, bir çok sorunu da beraberinde getirmiştir. Işletmelerin bazan iflasına kadar götürebilen ve kullanılan yem ve yem l.ammaddelcri veya içme sularından kaynaklanabilen şç̧itli olumsuzluk faktörleri hayvanlarda genellikle sebebi kısa sürede belirlencmeyen ölüm, yemden istenen ölçüde yararlanma ve canlı ağırlık kazancının ya da rerimin azalmasıra yol açabilmektcdir $(9,12,17,19,21)$. Hatta. kronik mikotoksin zehirlenmelerinde olduğu gibi, mikotoksinler tarafmdan billhassa bağışıklık sistcminin baskı altına alınması vcya zayflatılması sonucu viral yada bakteriyel hastalıklar baskin hale geldikleri için, bu olumsuzluk faktörleri gözden de kaçabilmektedirler (4.7). Bu sebeple, hayvanlara verilen yemlerden ileri gelebilecek herhangi bir olumsuzluk durumundan şüphelerildiğinde, kullanılan yemlerde, öngörülecek analizler yanında, sistematik analizlerin de yapılması kaçınılmaz olmaktadir. Yemlerden ileri gelen olumsuzluk faktörleri kaynaklarına göre ilaç kullanımından ileri gelen olumsuzluklar $v c$ besinsel kaynaklı olumsuzluklar diyc ikiye ayrılarak incclencbilir. Besinscl kaynakl olumsuzluk faktörleri de doğal kaynaklı zehirli maddeler, çevre ve besin kirleticileri, yem ve yem hammaddelerinin hazırlanması ve üretim tekniklerinden ileri gelen saknncalar, hayvan yemlerine katılan beslcyici değeri olan bazı organik maddeler ve mikotoksinler başlıkları altında toplanabilir.

Bu makale kapsaminda, yem ve yem hammaddelerinde bulunan ve hayvanlarda gelişme geriliği, yemin iyi değgerlendirilememesi ve 
istenen ölçüde verimin alınamamasından başlayarak ölüme kadar gidebilen zehirlenmelere sebep olan besinsel kaynaklı organik yapıdaki olumsuzluk faktörlerinden başlıcalarmın irdelenmesi amaçlanmıştır.

\section{Doğal Kaynaklı Zehirli Maddeler}

Hayvanlarda sürekli olarak zchirlenme tehlikesi doğuran doğal kaynaklı maddeler arasında başlica mineral maddeler (arsenik, civa, kurşun, bakır, sclenyum, molibden, flor, kadmiyum gibi), alkcloidler (özellikle pirazolidin alkaloidleri, opium, nikotin gibi), glikozidler (özcllikle siyanogenetik glikozidler), fenolik bileşikler (tancnler, gossipol gibi), solanin ve saponinler, nitrat ve nitritler okzalat ve fitallar, vilaminler ile proteinlerin kullanımın bozabilen maddeler, guvalıra yol açabilen maddeler, östrojenik maddeler ve bazi vilaminlerden ileri gelcn zehirlenmelerc yol af̧abilen maddeler bulunur. Burada bu maddelere ayrı ayn değinilmey'ccek; sadece bazıları ana hatlariyla incelenecektir.

\section{Siyanogenetik glikozidler}

Yapisinda siyanhidrik asit (HCN) bulunduran ve bunu asidik veya enzimatik hidrolizle saliveren bitkilere siyanogenetik bitkiler adı vcrilir; cvcil halyvanlarda siyanürle zehirlenmelerin en önemli kaynağın bu bitkiler oluşturur. Siyanogenetik glikozidlerin (amigdalin, linemarin, sambunigrin, dhurrin, vicianin gibi) ayrışması sırasında, siyanür iyonu (CN-) yanında, bir şeker ve birde aldehid (en çok benzaldchid) açığa çıkar. Bitki dokusu sağlamken siyanür iyonu salıverilmez; ama, bu iyonu içeren glikozidi ihtiva eden yem veya bitkilerin yenilmesi ya da parçalanmasını takiben, sindirim işlemi sırasında, beta glikozsidaz'in (bu enzim litki dokularinda da bulunur) etkisiyle glikozidler önce siyanohidrinler (alfa-hidroksinitriller) ve şekere ayrışır. Siyanohidrinlere ise bitki dokularında bulunan ve bitki hücrelerinin parçalanmaları sonucu açığa çıkan bazı ayrıştırıcı enzimlerin (emülsinler, hidroksinitril liyazlar) etkisiylc siyanür iyonu salıverilir. Çok sayıda bitki ve meyve (kayısı, şeftali, kiraz, erik, elma gibi) ile sebzede (lahana, şalgam, turp gibi) siyanogenetik glikozid vardır; bu madde bitkilcrin kök, gövde, yumru, yaprak, çiçek, tohumlar gibi hemen her kısmında bulunur. Ama, tohumlardaki düzeyi genellikle düşüktür; bu scbeple, sorgum gibi yem maddeleri hayvan beslemede çok kullanılır. Yalnız, filizlenme sırasında 3-4 gün içinde sorgum tohumlarindaki siyanür yoğunluğu, kuru ağıllk esasina göre, $3000-5000$ ppm'c kadar çıkabilmektedir; genç-tazc yaprakları dhurrin glikozidi bakımın- 
dan çok zengindir. Bu sebeple, yenilmesini takiben hayvanlarda hızla ölüme yol açabilmektedir $(12,13,34)$.

Glikozid halinde siyanürün zchirleyici miktarm kesin olarak bclirlemek zordur. Zira, zchirliliği bitki ve hayvana bağlı bir çok faktöre göre önemli ölçüde değişebilmektedir. Şövleki, bitkide fazla miktarda siyanogenetik glikozid ve serbest $\mathrm{HCN}$ bulunması; bitkinin fazla miktarda ve hızla yenilmesi; glikozidi hidrolize edcbilen bitkiler ve hayvanların sindirim kanalındaki ayrıştırıcı enzim ckiraliği; hayvanların siyanür iyonunu etkinsizleştirme (methemoglobin " $\mathrm{mHb}$ " ve tiyosulfat vasıtasıyla) yeteneği; ve gevişenlerde rumen. $\mathrm{pH}$ 's1 glikozidlerin zehirliliğini etkiler. Mide $\mathrm{pH}$ 'sı glikozidin hidrolizini sağlayan enzimatik etkinliği bir ölçüde baskı altına alabilir; ama, yine de asidik hidroliz devam eder $(9,46)$.

Ağızdan $4 \mathrm{mg} / \mathrm{kg}$ dozda siyanüre eşit miktarda bitki yenilmesi hayvanlarda mutlak olarak ölüme sebep olur. Onun için, bitkilerde $200 \mathrm{ppm}$ 'den fazla HCN' bulunması hayvanlar için tehlikeli düzey olarak kabul edilir $(17,46)$. Bu sebeple ülkemizdc yemlerde bulunmasına izin verilecek maddelere ilişkin olarak hazırlanan bir yöneltmelikte (4) civcivlere verilecek yemlerde $10 \mathrm{ppm}$, diğer hayvan yemlerinde 50 ppm'den fazla HCN bulunmasına izin verilmemektedir. Vücut siyanür iyonunu bir yandan tiyosulfatla $\left(\mathrm{S}_{2} \mathrm{O}_{3}-\right)$ ve bir yandan da mHḅ'le bağlayarak ctkisiz kılmaya çalışır; ana, bu mekanizmaları yenebilecek miktarda siyanüre maruz kalındığında, sitokrom oksidaz'ın etkinliğinin engellenmesi sonucu hayvanlarda şekillenen hücre solunumunun yetmezliğine bağlı olarak ölüm oluşmaktadır $(46,50)$.

\section{Fenolik bileşikler}

\section{Gossipol}

Yemlere işlenmemiş pamuk tohumu unu vcya küspesinin yüiksek oranda katılmasıyla, özellikle et tipi piliçlerde olmak üzere, hayvanlarda yem tüketiminde azalma ve gelişme geriliği dikkat çekmektedir. Bu durum pamuk toliumunda yüksek düzeyde bulunan gossipoldan ileri gelmektcdir. Pamuk tohumunda 300-24000 ppm arasinda serbest ve bağlı halde gossipol bulunur; uygulanan yağ çıarma yönteminc göre (sıkma, sıkma-süzme ve doğrudan çözücüylc ckstraksiyon gibi) küspede ise 200-1000 ppm arasında serbest gossipol kalır. Böylece, ortamdaki gossipolun çok önemli bir kısmı (\% 80-98) tahrip edilmekte veya uzaklaştırılmaktadır; ama, bu işlemlerin çoğunda 
ısı tma da olduğundan, gencllikle gossipolla birliktc bulunan lizin parçalanmakta ve küspınir besleyici değcri azalmaktadır. Bu scbeple, bu şekilde hazırlanmıs pamuk tohumu küspesi katılmış yemler lizin yönünden desteklenmelidir $(6,9,46)$. Ülkemizde bazı yem ve yem hammaddelerinde bulunmasma izin verilen serbest gossipol miktarları ppm olarak şöylcdir: pamuk tohumu küspesi 1200, diğer yem hammaddeleri 20 ppm, gevişen hayvanlar için hazırlanan karma yemler $500 \mathrm{ppm}$, kanath karma yemleri (yumurta tavuğu yemleri hariç) ve tavşan karma yemleri 50 ppm ve diğer karma yemler 20 ppm (4). Gossipola gery̧ gevişenler, kanathlar ve tavşanlar özellikle duyarlıhk gösterirler; köpcklerin duyarlıh̆ğı da fazladır. Kanatl yemlerinde 160-600 ppm den fazla gossipol bulunmamalıdır; 240 ppm gossipol yumurta verimi ve yumurtadan civciv çıkma oranını düşürürken, 600 ppm'den fazla gossipol piliçlerde gelişmeyi baskı altına alır $(9,46)$.

Gossipol öncelikle kronik zehirlenmeye sebep olan ve vücutta birikebilen bir maddcdir; düşük düzeyde uzun süre alınmasıyla bir kaç ay içinde hayvanlarda yem tüketiminde azalma, gelişme geriliği, zayıflama, kıl renginde değişme, anemi (gossipolun demiri bağlaması sonucu $\mathrm{Hb}$ miktarnda, alyuvar, trombosit ve akyuvar sayısında azalma), güşüzlük, isteksizlik, yumurta veriminde düşme veya durma, yumurtadan civciv çıkma oranında azalma, yumurta sarısı (gossipoldemir bileşiğinden dolayı zeytin yeşili renk alma) ve akında (siklopropan yă̆ asitinden dolayı pembe renk :llma) renk değişiklikleri görülür $(6,12,42)$.

\section{Tannik asit}

Bitkilerde bulunan ve molckül ağırlı̆̆ genellikle 500'ün üzcrinde olan çoğul fenolik maddeler tanenler diye bilinirıer; çözünebilir ve kondense tanenler diye iki şekilde bulunurlar. Hepsinin de proteinleri bağlama ve kabuk oluşturma (büzüş̧ürücü ctki) gibi ortak özellikleri vardır. Tannik asit çözü̈nebilir tanenlerin temsilcisidir; kendiliğinden veya enzimatik olarak bu madde glukoz ve gallik asite (1 molckül glukoza karşılık 7 moleküle va.an sayıda gallik asit) ayrışır. Bu grupta bulunan diğer tancnler hidrolize olduklarında ellagik (gallik asit yerine) ve quinik asit (glukoz ycrine) oluştururlar $(41,42)$. Tannik asit çeşitli meşc türlerinde ve meşcnin değişik kısımlarında (meşenin filiz, kabuk ve yapraklarında $\% 7$, pelitte $\% 10$, pelitin kadehinde $\% 35$ ve trrnaklarında $\% 45$, mazıda $\% 70$ ) yüksck düzeyde bulunur; bu bakımdan, meşelikte otlayan hayvanlar için tehlike arzeder. Yine, 
özellikle kanatl yemlcrine katılan sorgum gibi yem hammaddelcrindeki tanen düzeyi hayvanların r.ormal gelişmesini bozabilccek ölçüde yüksck olabilmektedir $(33,46)$. Yemlerde bulunacak \% 1 oranındaki tanen kanatlılarda gelişme geriliğine ve verimin azalmasına yol açabilmektedir. Burada, tanenler tarafindan sindirim kanalı cpitel hücresi zarlarının dış yüzeyindcki sümüksel salgıda bulunan proteinlerin çöktürülmesi sonucu barsakların emme yetencğinin azalması, tannik asit tarafından, başta demir ve kalsiyum olmak üzcre, bazı mincral maddeler ilc glukoz ve metiyoninin emilmesinin smurlandırılması ve yemdeki proteinlerin tanenlerle çöktürülmesi öncnli rol oynamakta$\operatorname{dır}(9,25,45)$. Bu scbeple, yemlerdeki protein oranının yükseltilmesi, demir ve kalsiyum gibi mincral madde miktarlarmın arturilması ile tanenler bağlanarak, yükseltgenerek veya çöktürülerck etkisiz kılınabilmektedir. Sindirim kanalında tanenlerin hidrolizi ile oluşan çoğul fenoller (pirogallol, pirokateşol gibi) tanenden daha hızh emilirler; bunlar irkiltici ve alyuvarları parçalayıcı etkinlik gösterirler ve piliçler ile civcivler için. son derece zehirlidirler. Diğer taraftan, tanenlerin hidrolizi sonucu açığa çıkıp cmilen gallik asidin 4-o-metil gallik aside çevrilerek ctkisiz kılınmasında kolin ve metiyonin gibi metil grubu vericisi amino asitlere gerek vardır; bu durum da hayvanm metiyonin ihtiyacının artmasına yol açabilir. Yalnız, bu etkinin belirgin hale gelebilmesi için de yemdeki tanen düzeyinin $\% 5$ ve daha fazla olmasına gerck duyulmaktadır $(9,12,34,42)$.

\section{Nitrat ve nitritler}

Doğal azot dolanımının bir sonucu olarak (atmosferik azot-toprakta bakteriyel nitrat halinde tutulma-bitki proteinlerine çcurilmebitki ve hayvansal metabolizma artığı veya atığı olarak atılma-nitrat, üre ve amonyağa parçalanma-nitrat, nitrit ve amonyağa çevrilmeatmosfere tekrar saliverilme), toprak ve su yaninda, bitki, meyve ve tarımsal ürünlerde nitrat ve nitrit halinde azota rastlanır (46).

Tarımda azotlu gübrelcrin yaygın şckilde kullanılması, insan, hayvan ve cndüstriyel artıklardan kaynaklanan azotla, toprak, sular, tahıllar ve bitkilerin azot seviyesi giderek yüksclir. Ayrıca, bazı yabani ot ilaçları (fenoksi asetik asit türcvleri gibi), toprak $\mathrm{pH}$ 'sının düşmesi ve mincral madde (fosfor, molibden, kükürt gibi) noksanlıkları hayvanlar için tehlikeli olabilecek miktarlarda nitratın bitkiler ve otlarda birikmesine yol açabilmektedir. Yince, meteorolojik olayların da (toprak ısısının $13{ }^{\circ} \mathrm{C}$ 'nin altına inmesi, toprağın havalandırılması, 
nitrat reeüktaz'ın etkinliğini kısıtlayabilecck ölçüde ışığın. az "bulutlu havalarda olduğu gibi" olması, kuraklık, vb) bitkilerde nitratın toplanmasında katkısı vardır. Gcncllikle 1000 ppm'e kadar nitrat kapsayan yemler ve 100 ppm'e kadar nitrat içcren sular hayvanlar için gürenli düzeyler olarak kabul cdilir. Sulardaki nitrat seviyesi $125 \mathrm{ppm}$ 'i aştığında hayvanlarda kronik ve 500 ppm'i geçtiğinde akut zehirlenmclerle karşılaşılabilir. Keza 1000 ppm'den fazla nitrat içeren ot ve yemler hayvanlarda, yairu atma da dahil diğer kronik nitrat zehirlenmesi belirtilerinc yol açabilir. Yemlerdeki nitrat düzeyi 2100 ppm'i aştığında vitamin $A$ ve E'nin mctabolizması ile tiroid bezi görevinde bozukluk.lar kaçınılmaz şekilde dikkat çeker $(9,17,46)$.

Hayvanlarda nitrat ve nitritlerin. sebep oldukları olumsuzluklar bu maddelerin aslinda doğrudan ve dolaylı etkilerinin sonucudur. Yem, bitki ve sularla alınan nitrat sindirim kanalında amonyağa indirgenirken, bilindiği gibi, ara yerde nitrit iyonu da oluşmaktadır; yemlerdeki nitrat seviyesi güvenli düzeylerde olduğunda, sindirim kanalında şekillenen ve emilen nitrit iyonu hayvanda herhangi bir istenmeyen duruma, en azından farkedilebilir derccedc, yol açmamaktadır. Ama, yüksck düzeyde nitrat içeren yemin fazla miktarda yenilmesi durumunda, nitratın amonyağa çevrilmesi sırasında (nitrat-nitritdiazot oksit -hidroksilamin- amonyak) ara yerde oluşan nitritin şekillenme hızı yikımından fazla olmakta ve sindirim kanalında nitrit yoğunluğu yükselmektedir. Dolayısiyle, fazla miktarda şekillenen ve nitrata görc 5-10 kez daha etkin olan nitrit iyonu sindirim kanalından hızla emilerek dolaşıma girmektedir. Dolaşım da nitrit iyonu doğrudan öncelikle iki etkiye sebep olmaktadır; bunlardan birisi hemoglobini $(\mathrm{Hb}) \mathrm{mHb}$ 'e yükseltgemek diğcri de damar düz kasların gevşetmektir. Nitrit iyonu $\mathrm{Hb}\left(\mathrm{Fe}^{-2}\right)$ ile tepkimeye girerek mHb'e $\left(\mathrm{Fe}^{+3}\right)$ yükseltger; csasında vücutta bu çevrilme olayı her zaman oluşur ve ikincisinin miktarı genellikle $\% 1-3$ seviyesinde tutulur. Oluşan $\mathrm{mHb}$ oksijeni taşıyamaz ve Hb'in mHb'e çevrilme oranına göre (\% 5-90 arasinda) hayvanlarda doku hipoksisi belirtileri görülür. Nitrit iyonunun ikinci etkisi, yukarıda değinildiği gibi, damar düz kaslarını gevşetmesidir; bu durum kan basıncı ve kalp debisinin düşmesiyle sonuŗlanır. Bu ise, zaten azalmış olan kanın oksijen taşıma yeteneği ile doku perfüzyonunun düşmesine ve sonuçta, başta beyin olmak üzere, hayati öneme sahip doku ve organlarda enerji açığının daha da fazlalaşmasına yol açar; yani, mevcut mHb'emi belirtilerinin daha da kötüleşmesine önder olur $(17,46,48)$. 
Nitrat ve nitritlerin dolayl etkilerinin en önemlileri vitamin A ve iyot metabolizmasına olanlardır; nitratın, gevişenler de dahil, hayvanlarda karotenlerin vitamin A'ya çevrilmesini sınırlandırdığı ve bu vitaminin karaciğerde dcpolanmasını azalttığı, vitamin A ve karotenlerin sindirim kanalında parçalanmasına yol açtığı; ayrıca, troid bezine iyot girişini engellediği ve böylece bezde büyümeye yol açtığı bilinmektedir. Tüm bu etkileriyle, nitrat ve nitritler hayvanlarda, pek çoğu farkına varılmadan seyreden, yemden yararlanmanın düşmesinc, gelişme geriliğinc, verimin azalmasına, döl veriminin düşmesine, yaşama gücü zayıf ve bakar körlüklü yavru doğum sıklı̆̆ınn artmasına, hastalıklara direncin kırılmasına yol açabilmektedirler (17, 46). Ülkemizde karma yemlerde bulunmasına izin verilecek nitrit düzeylerine ilişkin tolerans düzeyleri belirlenmiştir; ayrım yapılmaksızın karma yemlerde sodyum nitrit halinde $15 \mathrm{ppm}$ düzeyinde nitrit bulunmasına izin verilmektedir (4).

\section{Alkaloidler}

Hayvanlarda zehirlenmelere sebep olabilen çok sayıda alkaloid varsa da, bunlar içinde acı baklada bulunan lupinin özellikle önem taşır; acı bakla alkaloidleri soğuk kanlı hayvanlarda zehirli olmadıklarından, acı bakla bilhassa sazan balıkları için önemli bir yem hammaddesi durumundadır. Yapılan bitki ıslah çalışmalarıyla, bugün zehirli olmayan acı bakla tipleri geliştirilmiş durumdadır (9). Kanarya otları gibi çok sayıda bitki türünde bulunan pirazolidin alkaloidlerinin (retrcrsin, jakobin gibi) özellikle sığırlar tarafindan uzun süreyle yenilmesiyle bilhassa karaciğer rahatsızlıklarıyla seyreden (karaciğer sirozu, nekroz, sarılık, alyuvarlarda parçalanma, tümoral oluşumlar gibi) zehirlenme belirtileri dikkat çeker; koyunların rumeninde bu alkaloidler kısmen parçalandıkları için, bu hayvanlar pirazolidin alkaloidlerine oldukça dayanıklıdırlar $(29,46)$. Gevişenlerde Phalaris tuberosa gibi bitkilerin yenilmesiyle bilhassa merkezi sinir sistemine (MSS) ilişkin belirtilcrle seyreden zehirlenmeler görülür; bu bitkide bulunan alkaloidler monoamin oksidaz'm etkinliğini engcllerler. Böylece, katekolaminlerden, öncelikle serotoninin yıkımlanması engellenerek, MSS'nin hareket ve davranışlarla ilgili düzcni bozulur (15). Diğer yandan, patates ve benzeri yumrulu bitkilerde bulunan solanin gibi gliko alkaloidler, bilhassa sığırlarda olmak üzcre, hayvanlar için zehirlenme tehlikesi doğururlar (9). 


\section{Vitaminlerin kullanım veya otkinliğini engelleyen matdeler}

Yem ve yem hammaddelerinde çeşitli vitaminlerin kullanımını bozan çok sayıda madde bulunabilmektedir. Ham soyada karotenlerin yükseltgenmesi ve parçalanmasına yol açabilen lipoksidaz vardır; buzağ yemlerindeki ham soya oranı \% 30 vc yukarı düzeyde olduğundan, plazmadaki karoten ve vitamin A'nın seviyesi önemli derecede azalmaktadır. Ham soyada yine vitamin A'nın etkisini engelleyebilcn bir madde vardır; soyanın $60 \mathrm{dk}$ süreyle ısıtılmasıyla gerek vitamin $\mathrm{A}$, gerekse vitamin $\mathrm{D}$ nin üzerinde olumsuz etkileri olan faktörlerin ylkımlanmasına yol açlı̀ $(20,22,28)$. Bezelye, fasulye, alfalfa (Medicago sativa) gibi bitkilerde vitamin E'nin kullanımını bozan ve böylcce bu maddeye ihtiyacı arturan faktörler bulunur. Keza, tath yoncada (Melilotus alba) bulunan melilotozid alkaloidinin ayrışma ürünü olarak şekillenen dikumarol kanın pıhtılaşmasını bozmaktadır (39). Yine, sorghumda yüksck düzeyde bulunan löysin niasin ihtiyacını artırmaktadır. Keten tohumunda piridoksinin etkinliğini engellcyebilen ve glutamik asitlc peptid bağıyla bağlanmış bir faktör (1-amino-Dpirolin, linatin) bulunur. Keten tohumunun suyla ckstraksiyonu ve ssıtılması bu maddeyi uzaklaştırarak besleyici değerini önemli ölçüde artırmaktadır. Keza, pişmemiş yumurta akında bulunan avidin sindirim kanalında biotini bağlar ve emilimini azaltır $(9,24,34)$.

\section{Vitamin zehirlenmesi}

Bu yönden bilhassa vitamin D'ye benzer etkileri olan etkin maddeler taşıyan bitkiler önem taşır. Bazı yabani bitki veya otlarda (Cestrum diurnum, yaban yasemini ve Solanum malocoxylon gibi) bulunan vitamin $D$ benzeri ctkili maddeler hayvanlarda önemli kayıplara sebep olabilmektedir. Etkin vitamin $\mathrm{D}_{3}$ 'c benzemcyen karmaşı bir mekanizmayla bu madde barsaklardan kalsiyumun emilimini art1rarak etki cder; dolaşımda yoğunluğu yüksclen kalsiyum, öncelikle kalp kası ve beyin olmak üzere, yumuşak dokularda çökcrek sertleşmeye ve böylece bu organ ve dokuların görevlerini yapamamasına sebep olur (8).

\section{Metalleri bağlayan maddeler}

Başta ham soya olmak üzerc, bir çok bitki çeşidi ve yem hammaddesi kapsadıkları fitik asit, okzalik asit gibi maddelerden dolayı, sindirim kanalından, öncelikle çinko, demir, manganez, bakır, kalsiyum 
ve fosfor olmak üzere, mineral maddelerin emilimini azaltarak, bunlara ihtiyaci artirtrlar (14).

\section{Östrojenik maddeler}

Alfalfa, üçgüller, soya fasulyesi gibi bitkilerde izoflovanlar ve koumestenlar gibi biyolojik etkileri birbirine benzeycn östrojenik etkili bir dizi madde vardır; bu bitkilerde bulunan izoflovanların başlıcaları genistein ve biochanin; koumestanlarmki ise koupestroldur. Izoflovanlar bitkilerde genellikle bağh halde ve muhtemelen de glikozid şeklinde (genistein glikozidi genistin gibi) bulunur; hekzanla yağı alınmış soya ununda $\% 0.1$ dolayinda genistein bulunabilmektedir. Soya fasülyesinin 1 kg'ının östrojenik etkinliği $6 \mathrm{mg}$ dietilstilbestrol'unkine (DES) eşittir. Diğer yandan, uterusta büyümcye yol açma bakımundan genistein DES'den 100000 , estrondan 6900 ve koumestrol'dan $35 \mathrm{kcz}$ daha zayıf etkilidir; intrinsik etkinliğin bu ölçüde zayıf olması aslında bir şanstır. Yalnız, özellikle inek ve koyunların bu tür maddelcri uzun süreyle yemelcri veya otlamaları durumunda, kısırlıktan-yavru atmaya ve verim azalmasına kadar giden yetiştirme problemleriyle karşılaşılması kaçınılmaz olmaktadır $(30,38,46)$.

\section{Guvatur yafrce maddeler}

Çeşitli yem ve yem hammaddelerinde bulunan nitratlar yanında, bilhassa kolza, lahana, şalgam gibi bitki ve sebzelerde bulunan glukosinolatlar (tiyoglikosidler) tiroid bezi hormonlarmın sentezi ve salgılanmasinı engellcyerek bezde büyümeye sebep olurlar. Kolzada bulunan proqoutrin tiyoglikosidaz'ın (bitkisel bir enzimdir) aracılığında glukoz, asit sulfat vc jsotiyosiyanata ayrıştırılır; son madde ise daha sonra goitrine (5- vinil oksazolidin-2-tiyone) dönüştürülür. Esasta guvatıra yol açan madde budur. Kolzada bulunan guvatıra sebep olan madde ısıya duyarlıdır; yani, isıtılarak tahrip edilebilir. Soya fasülyesinde bulunan küçük molekül ağırlıklı bir peptid de, tiroid bezine iyot girişini bozarak, guvatıra sebep olabilmektedir $(9,26)$.

\section{Saponinler}

Saponinler çok sayıda bitki (bilhassa baklagiller) ve tarımsal üründc bulunan glikozidik yapıda, azotsuz, suyla köpürcn, deri ve mukózalarla temasa geldiklerinde yangıya ve alyuvarların parçalanmasina yol açan maddelerdir; hidrolize olduklarnnda şekerler ve ste- 
roid veya triterpenoid yapıdaki sapogenollere ayrışırlar. Yukarıda belirtildiği gibi, öncelikle hücresel ve zarsal kısımlarla etkileşme gösterirler; zar proteinleri, fosiolipidler ve kolesterolle etkileşmeleri sonucu alyuvarları parçalarlar. Saponinler anılan ctkileri neticesi hücre zarlarının geçirgenliğini de değiştirirler. Saponinlerin hücre zarlarına yönelik etkileri yüzey gerilimini değiştirmeleri, dayanıklı ve yayılabiIen köpük oluşturmaları esasına dayanır $(26,32)$. Yemlerle birlikte alnar saponinlerin hayvanlardaki etkilerine ilişkin yeterli bilgi yoktur ve bunlar hayvandan hayvana göre de değişebilmektedir. Evcil hayvanlar içinde bilhassa civcivler baklagil saponinlerine duyarlılı gösterirler; yemdeki kaba yonca saponini $\% 0.2$ olduğunda, hayvanlarda yem tüketimir.de azalma ve gelişme geriliği dikkat sekmektedir. Yemdcki yonca unu oranı \% 20 ye ulaşığında (normalde $\% 3$ dolayındadır) yumurta verimi önemli ölçüde azalmaktadır (11,34).

\section{Zehirli protein ve peptidler}

\section{Hemaglütininler}

Ham soya içerdiği hemaglütininlerden (lektinler) dolayı, antikorlara benzer şekilde, alyuvarların parçalanmasına veya bir araya gelmelerine sebep olur; hcmagalütininler, soya fasülyesi yanunda, hint yağı meyvesi, muz, patates, buğday jermi, vb maddelerde de bulunurlar. Isıya duyarlı olan hemaglütininler, bu maddelerin işlenmesi sırasında kolayca parçalanıp tahrip olurlar. Lektinler, ayrıca, hayvanlarda sindirim kanalından besinlerin emilimini de sinurlandırırlar. Bu etkileriyle, özellikle piliçlerde olmak üzere, hayvanlarda gelişme geriliğine sebep olurlar $(9,27)$.

\section{Enzim etkinliğini engelleyen maddeler}

Uygun şekilde hazırlanıp kullanıldığında çok değerli bir protein kaynağı olan soya fasülyesi, özellikle ham ve iyi isıtılmadan ve rastgele kullanıldığında, bilhassa kanatlılarda olmak üzere, hayvanlarda çok yönlü olumsuzluklara yol açabilmektedir. Işlenmemiş soyanın taşıdığı cn önemli sakıncalardan birisi hayvanların sindirim kanalında proteaz etkinliğini engellemesidir. Ycterince ssitılmadan ycmlere katılan soya unlarında bulunan bu maddeler sindirim kanalındaki protein ayrıstrrıcı enzimlerin (tripsin gibi) etkinliğini engelleyerck, hem kendisindeki hem de yemdeki proteinlerin ayrışmasını ve böylece sindirimini engelleyebilmektedir. Bu etkiye, vücut pankreas bezinde büyüme ve 
tripsin salgısın artırma şcklinde cevap verir. Soyanın anılan istcnmeycn etkisi yemlerin bilhassa metiyonin ve sistein gibi kükürtlü amino asitlerle desteklenmesiyle büyük ölçüde engellenebilmektcdir. Diğer yandan, yer fistığ 1 unu tripsin ve patates kemotripsin etkinliğini engelleyen maddeler bakımından zengindir; bunların ısıtılması veya pişirilmesi söz konusu olumsuzluk faktörlerinin tahrip edilmesine ve böylece bu maddelerin besin değerlerinin artmasına sebep olur $(9,51)$.

\section{Diğer bazı maddeler}

Lahana çeşitlerinde bulunan s-metil sistein sulfoksit sığırların rumen mikroorganizmaları tarafindan dimetil sulfoksitc çevrilip hayvanlarda iştihanın kaybolması, alyuvarların parçalanması, anemi ve sarllı̆̆a yol açar (9).

\section{Çeure ve besin kirleticileri}

Endüstriyel gelişmenin bir sonucu olarak, endüstriyel tesislerden kaynaklanan artık ve atıklarla yem ve yem hammaddeleri önemli ölçüde kirlenebilmektedirler. Her yıl milyonlarca ton miktarında üretilen ve o ölçüde de tüketilen kimyasal maddeler arasinda özcllikie metaller (arsenik, bakır, civa, kurşun, çinko, kadmiyum gibi), pestisidler (insektisidler, fungusidler, fumigantlar, herbisidler gibi), plasiik maddeler, deterjanlar, klorlu hidrokarbonlar, fözücüler ve petro-kimya ürïnleri önemli yer tutarlar $(9,47)$. Belirtilen maddelerin kullanımından kaynaklanan artık ve atıklar çcvrenin ve dolayısiyle bitkisel bcsinler ve sonuçta yem ve yem hammaddeleri ile hayvan topluluklarının önemli ölçüde kirlenmelerine sebep olurlar.

Tarımda verimi artırmak, ve ürün niteliğini iyileştirmck amacıyla özellikle gübreler (azotlu, fosfath, potaslı gibi) ve pestisidler yaygın ve yoğun olarak kullanılmaktadır. Tarımsal mücadelede insektisid, fungusid ve yabani ot ilaçlamın ayrı bir önemi vardır. 1940'l yılların başından itibaren, bilhassa sıtmaya karşı kullanılmaya başlayan DDT ve diğer klorlu hidrokarbonlar tarımsal mücadelede de geniş ölçüde kullanılmışlardır; ama, kalıcı ctkili olmaları, böylece çevre ve besir. kirlenmelerine yol açmaları dolayısiyle, endosulfan dışındakiler, bugün tümüyle yasaklanmışlardır. Klorlu hidrokarbonlar kimyasal ve biyolojik etkilere son derece dayanklı, yağ ve organik çözücülerde iyi çözünürler; metoksiklor dışındakiler vücut yağında yüksek düzcyde birikirler. Vücuda girdikten sonra DDT süt ve yumurta gibi bcsinlerle 
de atılır. Yemlerde bulunan klorlu hidrokarbonlar özcllikle kanatllarda yumurta verimi, döllenme, yumurtadan civciv çıkma oranı, yaşama gücü ve yumurta kabuğunun şekillenmesi ile kalınlığ üzerindc olumsuz etkilere önder olurlar $(12,16,37,52)$.

Organik fosforlu ve karbamat bileşiklerin, akut zehirlcyici etkilerinden öteye, kronik etkileri de vardır; organik fosforlu inscktisidlerden bazılarının (haloksan, karboferotiyon, fenitrotiyon, EPN, lcptofos, siyanofenfos, butifos, mefos ve mipafoks gibi) piliç, buzağı, kedi, tavşan, kuzu, domuz gibi hayvanlarda sinir sistemi üzerinde gecikmiş nitelikte zehirliliklcri vardır. Yin.e, organik fosforlu bileşiklerden. bazılarının (diazinon, mctamidofos, mevinfos, diklorvos, paratiyon gibi) teratojenik; bazılarının da (öncelikle paratiyon ve fosfolan olmak üzere, zayıf derecede de olsa, diğer organik fosforlu bileşiklerin hemen tamamının) kaslarda rekroz yapıcı ctkileri vardır $(17,45,46)$. Karbamatlar arasında evcil hayvanlar için son derece zehirli aldikarb ve karbofuran gibi bazı insektisidler vardır; bunlardan aldikarb bilinen en zehirli kimyasal maddelcrden birisidir ve kalıcı etkinliği de vardır $(12,46)$. Depolanmıs tarımsal ürünler, yem ve yem hammaddelerinde böcek ve ratlara karşı mücadelc için. tütsüleme veya gaz halinde bir çok madde (metil, brömür, etilen oksit, siyanür, fosfin, etilen dibromür gibi) kullanılır; uygulanmalanını takiben büyük bir kısmı ilk gün içinde ortamın havalandırılmasıyla ortamdan kolayla uzaklaştıkları için tütsüleme güvenli bir uygulama olarak kabul edilir. Ama, bunlardan bazıları ycm ve yem hammaddelerindeki bazı maddclerle birleşerek, bir yandan zchirli ürünlcrin (klorohidrin, $\mathrm{N}$-metilli bileşikler, metoksi- ve tiyometoksi bileşikler, dimetil sulfok-. sit gibi) şckillenmesine, bir yandan da besin değeri kaybına yol açabilmektedirler. Bunlardan bilhassa klor dioksit yağların yükseltgenmesi ve acılaşmasına, tokoferollerin ve piridoksinin değişikliğc uğramasına sebcp olabilmektedir. Yukarıdaki maddelerin aksine, etilen dibromür yemlerde hayvanların sağlığ vc verimini olumsuz yönde etkileyclbilccek ölçüde kalıntı (10 ppm ve daha fazla) bulunmasına yol açabilmektedir; bu maddenin kullanıldığı depolarda bulunan yem ve yem hammaddeleri kanatllarda, bilhassa yumurta sarısına olan etkileri sonucu, yumurta veriminin düşmesine ve hatta durmasina, erkek hayvanlarda sperma üretiminin bozulmasina sebep olurlar (9).

Çcşitli kimyasal yapılarda (fenoksi ve klorofenoksi asit türevleri, dinitro bileşikler, fcnilüre türevleri, klorlu asitler, triazin türevleri, tiyokarbamatlar, amid bilç̧ikler, bipiridil bilcşikler, vb.) çok sayıda 
yabani ot ilacı bulunur; bunlardan dinitro bileşikler (dinitrofenol, dinitro-o-krezol gibi) dışındakilerin hayvanlar için akut zchirlilikleri zayıftır. Ama, klorofenoksi asit türevleri $(2,4-\mathrm{D}, 2,4,5-\mathrm{T})$ gibi bitkilerde nitrat ve siyanogenctik glikozidlerin birikmesine yol açmaları ve, ayruca, 2, 4, 5-T'nin içinde dioksin gibi kirleticilcrin bulunması yönlerinden ayrı bir önem taşırlar (46).

Genel olarak söylemck gerekirsc, ülkemizdc uygulanan tarımsal tekniklerin yetcrince ileri olmaması, tarımsal mücadele ilaçları konusunda çiftçiler ve tarım işçilerinin ycteri ölçüde bilgili olmamaları, bu maddelerin serbestçe üretilip satılmaları ve böylece rastgele kullanılmaları sonucu tarım ürünleri bunlarla ileri derecede kirlenebilmektedirler.

\section{Yemlerin hazırlanması we üretim tekniklerinden ileri gelen sakıncalar}

Hayvan yemlerinde bitkisel protein kaynağg olarak kullanılan yağlı tohum (ayçiçeği, soya, pamuk tohumu, yer fıstığı, vb) küspeleri genellikle bu maddelerin ezilmesi ve sıkma vcya endüstriyel çözücülcrle yağlarının alınmasını takiben kullanılırlar. Bu işlemlerde kullanılan yeterince temizlenmemiş çözücülerde bulunan klorlu naftalenler, makina yağı artıkları, poliklorobifeniller ve polibromobifeniller, polisiklik aromatik hidrokarbonlar ve diğer ağır petrol artıkları bu küspelerde kaçınılmaz bir şekilde kalabilmektedir. Ayrıca, trikloroetilen ve diklormetan da olduğu gibi, bazı halojenli hidrokarbonlarla yapılan ekstraksiyon sırasında küspeler bu çözücülerle ağır biçimde kirlencbilmektedir; üstelik de, bunların kullanıldığı küspelerdeki protcinlerin besin değeri azalmakta ve oluşan zehirli metabolitler, özellikle kanatlılar ve gevişenler olmak üzere, hayvanlarda toplu zehirlenmelere sebep olabilmektedir. Trikloretilenle muamele edilen soya ununun protein kısmunda, pankreas enzimlerinin etkisiylc küçük vc suda çözünebilen, hayvanlar için son derece zehirli ürünler oluşabilmektedir. Şekillenen maddelerden birisi uzun süreli depolama ve ssıtma şartlarına son derece dayanıklıdır ve sadece kuvvetli asitıerle hidrolize olabilmektedir. Zehirli faktörün trikloretilenle kazein veya laktalbumin aradaki tepkimcyle oluştuğu bilinmektedir. Trikloretilenin peptid veya amino asitlcric muamelesi sonucu, sadece $L$-sistcin veya $L$-glutasyonla tepkimeye girerck, önemli miktarda tepkime ürünü oluşturduğu anlaşılmıştır. Yine, sentetik S- (diklorovinil) L-sisteinin buzağılara verilmesiyle, trikloretilenle muamele edilmiş soya unundakine benzer klinik belirtilerle karşılaşılmaktadır. Sığır, at ve kanatlılar trikloretilen-. 
le muamele edilmiş soya küspesine son derece duyarlidırlar; bu madde hayvanlarda öncelikle kcmik iliğini baskı altına alarak aplastik anemiye sebep olur $(24,51)$. Diğer yandan, su ürünleri ve hayvansal artıkların un haline getirilmesi ve çeşitli yem hammaddelerinin hazırlanması sırasında uygulanan ısı işlemleri ile yem ve yem hammaddelerinin depolanmaları sırasında yapılarında bulunan yağlarda bozulma ve acılaşma ürünleri oluşabilmektedir. Bilhassa, yapılarında fazla miktarda doymamıs bağ bulunan yağ asitlerinin depolanmaları sonucu hidroperoksitlerin şekillenmesiyle sonuçlanmaktadır; hidroperoksitler kolayca ve hızlı biçimde güçlü ve hoş olmayan koku ve tada sahip maddelere parçalandıklarından, bu şekildeki yağ veya yemlerin isteyerek yenilmesi söz konusu olmamaktadır. Peroksit değeri 10'un altında olan yağlar organoleptik olarak farkedilebilir acılaşma gösterirler ve peroksit değeri 20'ye kadar olan yemlerin de hayvanlar üzerinde olumsuz etkisi genellikle olmamaktadır. Bu şekilde peroksit değeri yükselmiş ve acılaşmıs yağları içeren yemleri hayvanìar isteycrek yemedikleri gibi, kapsadıkları bozulmuş yağ ürünleri hayvanıarın sindirim kanalı mukozasını irkiltip hasara ve sonuçta, sürgün de dahil, vücuttan su kaybı vc beslenme bozukluklarına, bir çok vitaminin (A, D, E, K vc bir çok B grubu vitamin) ile yeme aroma ve tat veren maddeler ve ksantofillerin ykımlanmasına önder olabilmektedir (26). Diğer yandan, kolza yağında olduğu gibi, rötralizasyon için kullanılan anilinle yağ asitlerinin birleşmesi sonucu oluşan çeşitli yağ asitlerinin anilidleri, öncelikle kanathlar olmak üzcre, diğer hayvanlar ve insanlarda zchirlenmelere sebep olabilmektedirler.

\section{Yemlere katılan besleyici değeri olan bazı organik maddeler}

Burada, özellikle sığır besiciliğinde olmak üzere, gevişenlerde protein kaynaklı olmayan azot sağlamak için kullanian üre önem taşır. Üre, bilindiği gibi, tarımda gübre ve hayvan beslemede azot kaynaği olarak genis kullanım alanı bulan maddelerden birisidir. Bu sebeple, gerek yemlere hatalı katılması sonucu gerekse kazara yenilmemesiyle, özellikle gevişenlerde olmak üzerc, hayvanlarda zehirlenmelere sebep olur. Üre ve diğer protein olmayan azot kaynaklarının (amonyum fosfat gibi) en önemli özcliiklcri amonyak salıvermeleridir. Ürenin hidrolizi üreaz tarafından hızlandırılır; üreaz; aralarında soya ürünleri de dahil, pek çok bitkide ve rumen içeriğinde bulunur (17, 46). Gevişenlerde normal olarak protein olmayan azot kaynaklarından saliverilen amonyak amonyum iyonu $\left(\mathrm{NH}_{4}^{+}\right)$halindedir. $\mathrm{Bu}$ iyon. yüklü ve çözünebilir olması sebebiyle, rumın mukozasından pek emil- 
mez. $\mathrm{NH}_{4} \rightarrow \mathrm{NH}_{3} \div \mathrm{H}^{\circ}$ tepkimesinin pKa'sı 9.02 dir; yani, bu pH'da ortamda \% 50'ser oranda amonyum iyonu ve amonyak vardir. $\mathrm{pH}^{\prime}$ nın 9 ve altına inmesi ortamdaki amonyum iyonu yoğuniuğunun artmasına ve ayrıca ürcaz etkinliğinin zayıflamasma önder olur. Ama, ürenin fazla miktarda alınmasında olduğu gibi, rumen pH'sının 11 ve üzerine çıması hallerinde, bu sefer de fazla miktarda amonyak şekillenir; rumen pH'sının 8.4 olması durumunda toplam $\mathrm{NH}_{3} / \mathrm{NH}_{4}{ }^{\circ}$ ün 1/10'u amonyak halindedir ve bu durum zchirlenmeyi kolaylaştırir. Buna karşılı, pH 6.4 de bu oran 1/1000'dir; bu isc zchirlenmevi zorlaştırır. Amonyağın iyonize, yani yüklü olmaması, cmilmesi de dahil, biyolojik zarlardan geçişini kolaylaştırur. Bilindiği gibi, rumen içeriği vücut sıvllarına göre asidiktir ( $\mathrm{pH} \mathrm{6-7}$ arası); böyle bir ortamda amonyağın zaten emilmesi çok zordur: Ama, amonyak bazik tcpkimelidir ve rumenin pH'sın yükselrir; pH'nın artmasını takiben ortamda fazla miktarda amonyak bulunursa, bu emilir ve sistemik dolaşıma girer. Diğer yandan, hücre içinin $\mathrm{pH}$ 'sı vücut sivilarınınkinden clüşük oldığundan! ( $\mathrm{pH} 7$ dolaymda), amonyak hücrelere de kolayca girer. Kan dolaşımındaki tampon sistemleri kanın pH'sinı 7.4 de tutmaya çalışırlar; bu şartlarda dolaşımdaki amonyağın, tamamı olmasa da, öncmli bir kısnı amonyum iyonu şeklindedir; böylece, bu haliyle de hücrelere nüfuz edemez $(17,31)$. Amonyak, bilindiği gibi, hücrclerde metabolizma sırasında bir yan ürün olarak ortaya çıkar vc karaciğer tarafindan alınarak ya üreye çevrilir ya da glukuronik asitle birleştirilerek glutamin sentezindc kullan.lir. Amonyakla ilgili her iki etkinkinizleştirme olayı da cnzimatik niteliktedir ve sitrik asit siklusundan sağlanan sulsstratlara bağımlıdır (17).

Gevişenlerin yemlerine, bilindiği gibi, genellikle \% $1-3$ arasında ürc katılır; ama, haywanların önccden ürcye alışık olmaları durumunda bu oran \% 6'ya kadar artırlabilir. Tek mideli hayvanlar üreye oldukça dayanıkhdır; zira, bunlarda ürenin ne alkali hidroliz ne de üreaz ilc yeterince parçalanması söz konusu değildir. Yalrız, özcllikle kanatlılarda olmak üzere, yeterince isıtılmamıs fazla miktarda soya unu içeren yemlerin kullanılması durumunda, soya ununda bulunan üreaz veya protaz'ların etkisiyle ürc parçalanarak zehirlenmeler oluşabilmektedir $(17,31)$.

\section{Mikotoksinler}

Mikotoksinler mantarlar (küfler) tarafından meydana getirilen ve bunları ihtiva eden yem, yem hammaddeleri $v e$ besinleri yiyen hay- 
van ve insanlarda zehirlenmelere ve ölüme yol açabilen kimyasal maddelcrdir. Mikotoksin oluşturan mantarlar dünyanın her tarafında bulunur. Gerek sahada gerekse harmanlama, depolama, taşıma ve hazırlama aşamalarında, özcllikle ssı ve rutubet olmak üzerc, şartlar mantarların gelişmesine uygun olduğu takdirde, tarım ürünleri, yen ve besinler mantarların istilasına uğrayarak, mikotoksinlerle kirlenebilirler. Bu sebeple, yemlerden kaynaklanan çok çeşitli olumsuzluk faktörleri arasında mantar invazyonları ve mitotoksinlerden ileri gelen kirlenmelerle sık şekilde karşilaşılır. Bu kirlenmelerin doğurduğu olayların. hayranlarda pek farkına varılmadan seyretmesi de gerck hayvan sağlığı ve ckonomik işletmecilik yönünden gerekse kalıntıları vasıtasiyla topium sağhlğı üzerinde doğuracakları olumsuzluklar bakımından, günümüzde en fazla ilgi doğuran konuyu teşkil eder $(3,49,53)$.

Günümüze kadar varlığ ortaya konan mantar türlerinden 250 kadarının mikotoksin oluşturdukları, 20-25 dolayındaki mikotoksin grubunun da besin ve yemlerde doğal kirletici olarak bulundukları ve anilan yem veya besin maddelerini tüketme durumundaki, bilhassa kanatlllar olmak üzere, hayvanlarda sık sık zehirlenmelere yol açıkları bilinmektedir. Ayrıca, mikotoksinlerle kirli yemleri yiyen hayvanlara kadar ulaşabilen mikotoksin kalıntıları toplum sağlığı yönünden çok geniş boyutlu tehlike oluştururlar. Akut zehirlcyici etkilerinden öteye, başta aflatoksinler olmak üzere, bazılarının güçlü karsinojenik ve östrojenik etkilcri vardır $(3,7,44)$.

Doğal kirlctici olarak besin ve yemlerde bulunabilen, insan ve hayvanların sağlığı yönünden önemli mikotoksinlerden bazıları şünlardır: Aflatoksinler, okratoksinler, zearalenon, sitrinin, patulin, sterigmatosistin, trikotesenler $P R$ toksin, penisillik asit, sporidesmin, ergot alkaloidleri, streoviridin, alternariol, tenuazonik asit, rubratoksinler, sikloklorotin, slaframin, luteoskyrin, rugulosin, tremorin $A$, kojik asit, okzalik asit gibi $(7,23,47)$.

\section{Aflatoksinler}

Aflatoksinler (AF) A. flavus, A. paraziticus ile çç̧itli Aspergillus, Penisilyum ( $P$. puberulum gibi) ve Rhizopus türleri tarafindan hazırlanan mikotoksinlerdir. Özellikle sayılan iki tür dünyanın her tarafinda toprak ve havada yaygin olarak bulunurler. Aflatoksin terimi $\mathrm{AFB}_{1}$, $\mathrm{AFB}_{2}, \mathrm{AFG}_{1}, \mathrm{AFG}_{2}, \mathrm{AFM}_{1}$, ve $\mathrm{AFM}_{2}$ diyc bilinen 6 ana bileşiği karşllar. Ayrıca, bunlara ilaveten, gerek küflü kültürlerde gerekse canlı vücudunda şekillenenlerle beraber (Aflatoksikol "AFR,", $\mathrm{AFP}_{1}$, $A F Q_{1}, A B_{2 a}, A F G_{2 a}, A F G M_{1}, \Lambda F M_{2 a}, A F B_{3}$ gibi) aflatoksinlerin 
sayısı 20'yi aşmaktadır. $A F M_{1}$ "c $A F M_{2}$, sırasıla. $A F B_{1}$ ve $A F B_{2}$ ' nin sütle atılan metabolitleridir; $\Lambda F M_{1}$, bazan, misırda da bulunabilmektedir $(23,40)$. Aflatoksin şekillendiren mantarlar $24-25^{\circ} \mathrm{C}$ de ve $\% 15$ ve üzerindeki rutubet içeren hemen her çeşit tahıllar, yem ve yem hammaddeleri ile besinlerde kolayca ürcrler ve mikotoksin sentezleyebilirler. Normal ısılarda son derece dayanıkl olar. afıatoksinlerin tümüyle parçalanmaları için $300^{\circ} \mathrm{C}$ inin üzerindeki sicaklıklara gerck vardır. $\mathrm{Bu}$ sebeple, pastörizasyon ilc sütlerdeki aflatoksin miktarında azalma olmamaktadır $(1,2,7)$.

Yem ve besinlerle alınan aflatoksinler sindirim kanalından sınırlı ölçüde emilirler. Dolaşıma geçen toksinler plazmadan çabuk ayrılır; başlıca karaciğcr ve kaslarda dağılım gösterirler. Vücuda giren $\mathrm{AFB}_{1}{ }^{\prime}$ in \% 85-90'ı ilk 24 saat içinde dışkı (\% 75 kadarı), idrar ( $\% 15-20)$ ve sütle değişmemiş veya metabolitleri halindc çıkarılır. Dışkıyla bu ölçüde atılma durumu ağızdan alınan toksinin sindirim kanalından sınırlı şekilde emildiğini gösterir. Bulaşık yem veya toksinin verilmesinin durdurulmasını takiben 3-6 gün sonra sütle, 6-9 gün sonra da idrạr ve dışıda aflatoksin kalıntılarma rastlanmamaktadır. Alınan $\mathrm{AFB}_{1}$ 'in sığır ve koyunlarda yaklaş̧ı \% 0.1 'i sütle $\mathrm{AFM}_{1}$ ' halinde çıkarılır. Süt ineği yemlerine $400 \mathrm{ppb}$ ve daha yüksek düzeylerde $\mathrm{AFB}_{1}$ bulunması yavrularını zchirleyebilccek miktarda sütle $\mathrm{AFM}_{1}$ çıkarılmasına yol açabilmektedir. Kanath yemlerindeki toksinin yaklaşık $\%$ 0.5'i yumurtaya geçcbilmektedir. Şöyleki, $100-200$ ppb AFB ${ }_{1}$ ihtiva eden yemi yiyen kanatlıların yumurtalarında $0.2-3.3 \mathrm{ppb}$ kalınt bullunabilmektedir. Bu tür yumurtaları tüketenlerdc, söz konusu düzeylcrdeki aflatoksin kalıntıları herhangi bir olumsuz etkiye sebep olmakla beraber, yumurta sarısinda \% 50ye varan oranda embiryo ölümüne yol açabilen aflatoksin miktarının $0.9 \mathrm{ppb}$ (yaklaşı $48 \mathrm{ng}$ / yumurta sarısi) olduğu dikkate alınırsa, konunun özcllikle damızlık tavuk işletmeleri yönünden ne kadar önem taşıdığı kolayca anlaşılır $(10,23,44,46)$.

Zehirlilik bakımından en güçlü olanı $\mathrm{AFB}_{1}$ 'dir; bunu azalan s1rayla $A F G_{1}, A F B_{2}$ ve $A F G_{2}$ izler. $A F M_{1}$ 'in etki gücü $A F B_{1}$ ölçüsündedir. $\mathrm{AFB}_{2}$ 'nin etki gücü ise $\mathrm{AFB}_{1}$ 'nin ancak \% l'a kadardrr; bu durum alınan $\mathrm{AFB}_{2}$ 'nin vücutta önce $\mathrm{AFB}_{1}{ }^{\circ} \mathrm{c}$ ve sonra da etkin metabolitlere dönüşürülmesiyle ilgilidir. Hayvanların çoğunda $A F B_{1}$ 'in ÖD ${ }_{50}$ değeri $0.5-1.0 \mathrm{mg} / \mathrm{kg}$ arasında değişir. Diğer yandan, evcil hayvanların çoğunda zehirlenme oluşturabilen yemlerdcki aflatoksin düzeyleri $10-100 \mathrm{ppm}$ arasındadır. Bu değer ördekler için $0.3 \mathrm{ppm}$ ve 
buzağılar için de 2.2 ppm dolayındadır. Yemlerde 200 ppb'ye kadar bulunacak aflatoksin düzcylerinin hayvanlarda klinik olarak herhangi bir etkisi olmamaktadır. Diğer yandan $10 \mathrm{ppb}$ 'den fazla toksin içeren yemleri yiyen hayvanların süt ve yumurtalarında kalıntı bulunabileceği göz önünde tutulmalıdır $(17,23,35,49)$.

Hayvanların duyarlılığı ve alınan toksin miktarına bağlı olarak :f flatcksinler akut, subakut ve kronik nitelikte zchirlenmelere yol açarlar. Son durum, hayvanlarda, öz@llikle bağıłıklık sisteminin baskı altına alınması ve kazanılmıs dircncin kırılmasına yol açarak, bir çok hastalığın ön plana çıkmasına sebep olduğundan, çoğu kez gözden kaçabilmektcdir. Diğer yandan, gelişme hızında yaraşlama, yemin değcrlendirilmesinde azalma, karkas kalitesi ve hastalıklara dirençte düşme ve bağışıllık sisteminin baskı altına alınması yemlerdeki küçük miktarlarda bulunan toksinin yol açtığı etkiler olup, bunlar daha az tehlikeli ama ekonomik yörden önem taşırlar $(44,47)$.

Aflatoksinlerle akut zehirlenmeler hayvanlarda ani ölüm veya iştihasızlık, solunum güçlüğü, burun akıntısı, durgunluk, kansızlık, öksürük, kanlı sürgün, çırpınnılar, bitkinlik ve hızlı ölümle scyreder $(17,23)$. Subakut olaylarda sarılık, hematom, kanamalı barsak yangısı, trombosit sayısında azalma ve yukarıda sayılan belirtiler şiddeti azalmış şckilde görülür. Akut ve subakut olaylarda etkilenen. hedef organ karaciğcrdir. Zehirleyici olabilecek miktarlarda $\Lambda \mathrm{FB}_{1}{ }^{\prime}$ in alınmasını takiben 3-6 saat içinde karaciğer görevinde bozukluk ve yağlı değişiklikler ortaya çıkar; bunları karaciğer nekrozu izler. Anılan karaciğer hasarı pıhtılaşma mskanizmasının bozulmasına, sarılığa ve karaciğer kaynaklı serum proteinlerinde azalmaya yol açar. Kanın pıhtılaşma yeteneğinin bozulması ve kapillar damarların kolayca çatlayabilmeleri sonucu vücudun mukoz zarları ve boşluklannda yaygın kanamalar oluşur. Yemde bulunan 1-1.2 ppm $\mathrm{AFB}_{1}$ tavuk ve etlik piliçlerde akut karaciğer yangısı, şiddetli kanama ve ölüm yapabilmektedir. Diğer yandan, böbrek tubüllerinde nekroz ve, bursa fabrisius da dahil, lenf dokuda küçülme dikkat çeker $(3,17,47)$.

Kronik zehirlenme gelişme hızı, yem tüketimi ve yemden yararlanmanın azalması, kıl örtüsünün bozulması, kansızlık, özellikle etlik piliçlerde karkas kalitesinde düşme ve berelenme-çürüme oluşması, karnın büyümesi (karın boşluğunda sıvı toplanmasından dolayı), hafif sarılık, iştihasızlık, hem doğal (makrofajlar ve komplemen aracılı), hem de kazanılmuş (hücresel ve humoral) bağışıkhğın baskı altına alınması ve strese uyum yeteneğinin bozulmasıyla seyreder. Gerek bağışı- 
lığın yetersiz kalmasında gerekse doğal direncin kurlmasında aflatoksinler hazırlayıcı faktör olarak iş görürler; zira, ortaya çıkacak belirtiler aflatoksin zchirlenmesinden ziỵade bulaşıcı bir hastalığı gösterecektir. Sığırlarda yavru atma, süt veriminde azalma veya tümüyle kesilme oluşabilir. Scrum ve karaciğerdeki vitamin A düzeyi azalır ve protein sentezi bozulur. Protein sentezinin engellenmesi yemle alınması gereken protein miktarın (veya protein ihtiyacını) artırır. Kanatllarda, ayrıca, yumurta verimi, yumurtadan civciv çıma oranı düşer ve vumurta ağırlıkları azalır $(18,23,35,46)$.

Aflatoksinler bilinen en güçlü karaciğer karsinojenidirler. Maymunların da aralarında bulunduğu çok sayıdaki hayvan türünde kanser oluşumuna yol açarlar. Yemlerdeki:15 ppb'lik aflatoksine bir sefer dahi maruz kalınması halinde dişi ratlarda 80, erkek ratlarda da 70 haftada \% 100'e varan oranda karaciğer kanseri oluşmaktadır. Hatta, yemleriyle verilen $1 \mathrm{ppb}$ aflatoksin bile ratlarda karaciğer kanserine yol açabilmektedir (23, 35, 53).

\section{Okratoksinler}

Okratoksinler, başta $A$. ochraceus ve $P$. viridicatum olmak üzere, bu iki türe bağlı ondan fazla suş tarafindan hazırlanan bir mikotoksin grubudur. Okratoksin -, B, C, A'nın metil ve B'nin metil ve etil esterileri gibi çeşitleri vardır. Bunlardan okratoksin A ve seyrck olarak da okratoksin B'ye yem ve yem hammaddelerinde kirletici olarak rastlanır $(7,40)$.

Hayvan türlerinin okratoksin A'ya duyarlılığı farklıdır; ÖD $D_{50}$ değeri $3.4-30.8 \mathrm{mg} / \mathrm{kg}$ arasında değişir. Dişilerin duyarlılı̆̆ daha fazladır. Etlik civcivlere yemleriyle $0.5-1 \mathrm{ppm}$ düzeyinde 3 hafta sürcyle verilen okratoksinin istenmeyen etkisi olmamaktadır; yine, $0.3 \mathrm{ppm}$ 'e kadar okratoksinin bu hayvanlara sürekli olarak verilmesinin de olumsuz etkisi görülmemektedir. Yumurta tavuklarına yemleriyle $0.5 \mathrm{ppm}$ düzeyinde 6 hafta süreyle verilen okratoksin yem tüketimi ve yumurta verimini azaltmakta, $4 \mathrm{ppm}$ miktarda ise yumurta verimi tümüyle durabilmektedir. Keza, son duruma gelişme ciddi biçimde gerilemektedir (23, 46).

Okratoksin A başlıca böbrek ve bir ölçüde de karaciğer zehiri olarak etkir. Zehirlenme hayvanlarda genellikle iştihasızlık, bitkinlik ve sürgün gibi genel belirtilerle seyreder. Günlük civciv ve ördeklerde böbrek, karaciğer ve ön midede kanamalar oluşur. Etlik civciv ıc pi- 
liçlerde belirgin bir gelişme geriliği dikkat çeker. Kanathlarda demir eksikliği tipinde hipokromik-mikrositer anemi şekillenir. Okratoksinler böbrekte tubuler hasar ve atrofi, glomerüler hiyalinizasyon ve interstisyel fibroza sebep olur; bu durum glomerüllerden süzülme, tubüllerden salgilama ve geri cmilmenin bozulmasina önder olur (12, $35,44)$. Okratoksinler bağışıllık sistemini de baskı altına alır (7).

\section{Zearatenon}

Zearalenon (F-2 toksin) F. roseum (Gibberella zeae) ve diğcr Fusaryum türü mantarlar tarafindan hazırlanan, fenolik rezorsilik asit türevi, büyük lakton yapılı bir mikotoksindir (40). Mantarların gelişmesi surasinda ssinın bilhassa $12-14^{\circ} \mathrm{C}$ nin altına inmesi ve tahllar, yem veya yem hammaddelerinin yüksek rutubetle ( $\% 23$ 'den fazla) depolanması zearalenon sentezini teşvik eder. Zearalenon şekillendiren mantarlar, başta mısır, arpa, yulaf olmak üzere, tüm tahıl ve otlarda gelişebilir ve mikotoksin oluşturabilirler. Zearalenon son derece dayanıklı bir maddedir; ısıtma ve diğer işlemlerden pek etkilenmez (7, 46).

Zcaralenon östrojenik etkili bir maddedir. Yemlerde bulunan mikotoksin düzeyi ve hayvanlarda karşlaşılan östrojenik etkiler arasında sıkı bir ilişki vardır; ama, östrojenik etki gücü zayıfır ve farelerde uterusda büyümeỵc sebep olma bakımından östronla karşılaştırıldığında, etki gücü ağızdan verilince 0.016'sı ve DA yolla uygulanenca 0.06 'sı kadardır. Düşük miktarda zearalenon ihtiva eden yemlerin dişi hayvanlara uzun süre verilmesi sonucu vulva ve vajinanın şişipkızarması, vajinal akıntıların artması, vajina ya da düz barsağın geriye doğru çıması, utcrus kanaması, uterusun büyümesi ve salgılarının. artması, memelerin büyümesi, süt gelmesi, yumurtalıkların küçülmesi, kızgınlığın görülmemesi veya sık sık olması, yavru atma, kısırlık ve gelişme geriliği gibi aşırı derecede öströjen. salgılanmasındakilere benzer belirtiler dikkat çcker. Erkeklerde ise dişilik belirtileri ve görünümü gelişebilir $(7,23,46)$. Zearalenona en az duyarlı hayvanlar kanathlardır; yeme katılarak verilen 25-100 ppm zearalenon bunlarda hiç bir olumsuz ctkiye yol açmamaktadır (23).

\section{Trikutesenler}

Trikotesenler, 4 halkalı, 12, 13-epoksi trikotes-9-ene çatısına sahip ve kültür ortamında $80^{\circ}$ den fazla türevi elde edilmiş bir mikotoksin grubudur (7). Ancak, bunlardan T-2 toksin, nivalenon, deoksini- 
valenol (vomitoksin, $\mathrm{Rd}$ toksin) ve diasetoksiskirpenol diye bilinen 4 türevi doğal kirletici halinde yem ve besinlerde bulunurlar ve diğerlerine göre daha fazla önem taşırlar.

Trikotesenler, Fusaryum, Scfalosporyum, Trikoderma, Trikotekiyum ve Miyrotesyum gruplarına dahil çok sayıda mantar türü tarafından hazırlanırlar. Tarım ürünlerinde sık sık küflü çürümeye scbep olduklarından, bunlar içinde Fusaryum türü mantarlar ayrı bir önem taşırlar. Diğerlerine tahıllarda seyrek rastlanır; ama, toksijenik suşları dünyanın her tarafinda bulunur $(7,46)$.

Trikotesenler hayvanlarda genellikle birbirierine benzer etkiler oluştururlar. Doğrudan temas halinde hepsi de deri ve mukozalarda şiddetli irkilti, yangı ve nekroza yol açarlar. Bu ctki temas halinde laboratuvar personelinde de görülür. $50 \mathrm{ng}$ gibi çok az miktardaki T-2 toksine rat veya kobay derisi duyarlhlık gösterir; bu test laboratuvarda trikotescnlerin tanısinda kullanilır $(7,17,46)$.

Trikotesenlerle subakut ve kronik olarak zehirlenen hayvanlarda ağız boşluğundan başlayarak tüm sindirim kanalı boyunca yangı ve noktalı-çizgili kanamalar, kan şckilli hücrelerinde azalma, kansızlık ve bağışıklık sisteminde zayıflama görülür. Hayvanlarda iştahsızlık ve kusmaya her zaman rastlanır. Ayrıca, sık sık pisleme ve arka kısımda felç oluşabilir. Trikotesenlerin karsinojenik olmadıkları ama teratojenik ctkilerinin bulunduğu anlaşılmıştır $(3,7)$.

\section{Satratoksinler}

- Satratoksinler Stachybotrys atra (S. alterans diye de bilinir) tarafından hazırlanan trikotesen türevi bir grup mikotoksindir; kromatografik özelliklerine göre satratoksin $\mathrm{C}, \mathrm{D}, \mathrm{F}, \mathrm{G}$ ve $\mathrm{H}$ diyc bilinen 5 türevi ayrılmışır. Satratoksinler diğer trikotesenlere benzer etki oluştururlar. Deri ve mukozalar için son derece irkilticidirler. Etkilenen hayvanlarda önce ateş, sürgün, tükrük salgısında artış, süt veriminde azalma ve iştahsızlık dikkat çeker. Sonra sürgün şiddetlenịr, kas seyrimeleri ve çırpınmalar görülür. Hayvanların kanındaki lökosit sayısı 500-700/ mm3'e kadar inebilir. Zchirlenmenin başlamasını takiben 4-6 gün içinde ölüm oluşur $(7,46$ ).

\section{Sporidesminler}

Bunlar, Sporidesmium bakeri (Pithomyces chartarum) başta olmak üzere, bir çok toprak mantarı tarafından hazırlanan bir scri (sporides- 
min $\Lambda-J)$ mikotoksindir. Sporidesminden öncelikle koyun ve kısmen de sığırlar etkilenir; 3 günde toplam $3 \mathrm{mg} / \mathrm{kg}$ dozda verilen sporidesmin 4 gün içinde \% 100'e varan ölüme sebep olabilmektedir. Bu maddenin bazı hayvan türlerinde ölüme yol açabilen ağızdan toplam dozları $\mathrm{mg} / \mathrm{kg}$ olarak şöyledir (5): Sı ğır ve koyun 1; tavşan 1-2; kobay 2-4; piliç 5-10; rat 20-30; ve farc 200-300. Sporidesmine maruz kalan hayvanlarda bilhassa safra yolları ve karaciğer hücrelerinde hasar görülür; bunun sonucu klorofilin etkin bir metaboliti olan filloeritrin vücutta birikir. Dolaşıma geçen bu madde vücudun kılsız ve renksiz kısımlarının doğrudan güneş ışığına maruz kalmasıyla da, ışı̆̆a aşırı duyarhlığa yol açar. Sporidesminin biyolojik olarak etkinliği hemen tümüyle kükürt içeren kısmıyla ilgilidir. Sporidesminin yenilmesinden sonra, alınan miktarına bağlı olarak, 1 ș̆ğa aşırı duyarlılık, ağırlık kaybı, sarılık, karaciğer bozuklukları ve 3-5 gün içinde ölüm oluşur; yalnız, sarılık ve ışı̆̆a aşırı duyarlılık tepkimelcri her zaman görülmeyebilir (5, 46).

\section{Ergot alkaloidleri}

Ergot çavdar ve diğer tahıllarda parazit olarak yaşayan Claviceps purpurea isimli mantarın ürünüdür; bir kaç santimetre uzunluğunda ve ince koyu renkte bir madde olan ergotta, aminli ve amino asitli alkaloidlerin yanısıra, histamin, tiramin, kolin, asetil kolin, izoamilamin gibi pek çok madde daha vardır. Doğal ergot alkaloidleri denilince akla gclenler liserjik asitin amid türevleridir. Bu asite bağlanan gruplara göre de ergot alkaloidlcri amino asitli ergot alkalokidleri (ergopeptid alkaloidler) ve aminli ergot alkaloidleri diyc ikiyc ayrllırlar. Amino asitli maddelerin başhıcaları crgotamin ve crgotoksin (crgokornin, ergokristin, alfa-ergokriptin ve beta-crgokriptin isimli 4 maddenin karışımıdır), aminli alkaloidlerin en önemlileri ise ergonovindir; bu madde ergobazin veya ergometrin olarak da bilinir $(9,46)$.

Ergot kirliliğinin zchirliliği içerdiği alkaloid çeşidine, bileşimine, farklı Claviceps purpurea suşlarına göre önemli dereccde değişebilmektedir. Tahıllar, karma yemler ve yem bitkilerinde bulunan ergotla genellikle kronik nitelikte zehirlenmeler görülür; akut veya kronik zehirlenmeye yol açabilen crgot miktarları hakkında yeterli bilgi yoktur. Yemle birlikte alınan toplam 6- 159 ergot tavuk ve güvercinlerde, $60 \mathrm{~g}$ crgot da ördeklerde öldürücü olmaktadrr. Keza, haftada 2 kez $40 \mathrm{~g}$ miktarmda yedirilen ergot gebe ineklerde yavru atmaya, $100 \mathrm{~g} /$ hayvan/gün miktarda 11 gün süreyle verilen ergot da topallık ve vücudun 
ęłkıntılı yerlerinde nekroza sebcp olmaktadır. Alan şartlarında görülen ergot zehirlenmeleri gencllikle \% 1 dolaynda ergot sklerotuyla kirlenmis yem veya otların tüketimiyle ilgili olmaktadır. Insan ve hayvan besini olarak kullanılarak tahılların, bu sebeple, \% 0.3 den fazla ergot sklcrotu içermemesi gerekmektedir; ağırlık esasına göre ergotun $40-50 \mathrm{mg} / \mathrm{kg}$ miktarları hayvanlar için zehirlcyici olarak kabul cdilir $(36,46)$.

$\mathrm{Bu}$ maddelerin ctki şekli esasta farmakolojik etkilerinin abartılmıs biçimde yansımasının bir sonucudur. Bilindiği gibi; ergot alkaloidleri alfa-adrenerjik reseptör blökörlcridirler; ama, çoğu etkileri bu etki biçimiyle açıklanamayacak ölçüde de karmaşıktır. Örneğin crgotamin çevre damarlarda daralma, vazo-motor merkczde baskı ve çevresel adrencrjik reseptörleri bloke ederken, ergonovinin alfa-adrenerjik reseptörlerde uyarı geçişini engelleyici etkisi yoktur. Ergot alkaloidleri uterus ve damar düz kaslarını şiddetle büzcrler; diğer düz kaslara etkileri zaylftur. Damarlara olan etkileri sonucu doku ve organlardan geçen kan akımını azaltırlar; damar endotelinde de hasara sebep olurlar. Son durumdaki etki şckilleri tam bilinmemektedir; ama, damar daraltıcı ctkilcri gangrene yol açan özellikleriyle birlikte gider. Burada, vücudun, bilhassa çıkıntılı yerlcrindeki damarlarda yerel dolaşımı engelleyecek ölçüde daralma yapmalarının katkısı vardır; buralarda önce damar stazı, siyanoz, soğuma, tromboz ve sonra da doku ölümüne sebep olmaktadırlar. Ergot alkaloidleri MSS ni önce hafif şekilde uyarır ve sonra baskı altnna alırlar; vazomotor ve solunum merkezlerini baskı altına alan bu maddeler medulladaki kemoreseptör trigger zonu uyararak (dopamin-2 reseptörleri aracıliğında) kusmaya yol açarlar $(9,36,46)$.

\section{Rubratoksinler}

P. rubrum ve $P$. purpurogenium isimli mantarlar tarafindan rubratok$\sin$ : A ve $B$ diye bilinen iki mikotoksin oluşturulur. Anılan mantarlar yem ve tahıllarda çoğunlukla Aspergillus türleriyle birlikte bulunur ve ürerler; böylece, ayn ortamda aflatoksinlerle birlikte bulunabilirler ve birlikte seyreden zehirlenmelere yol açabilirler. Keza, depo yemlerinde aflatoksinlerin şckillenmesini kolaylaştıran faktörler rubratoksinlerin oluşumunu da teşvik ederlèr $(7,40)$.

Rubratoksinlerden hemen tüm hayvanlar etkilenir. Rubratoksin B'nin ratlarda ăğıdan $\dddot{O D}_{50}$ değeri $400-450 \mathrm{mg} / \mathrm{kg}$ arasında değişir. Rubrratoksinler hayvanlarda iştihasızlık, su kaybı, durgunluk, sürgün, 
sarılık, ağırlık kaybı, organ ve dokularda kanamalar, böbrek tubül hücrclerinde soysuzlaşma ve karaciğerde nekroza yol açar. Teratojenik ve embiryo öldürücü etkileri de vardır $(7,46)$.

\section{Silrinin}

Bu P. citrinum ve bir dizi Penisilyum ve Aspergillus cinsi mantar tarafından hazırlanan bir mikotoksindir. Öncelikle civcivlerde olmak üzere, hayvanlarda su tüketiminde artma, sürgün, jejunumda kanama, karaciğerde mozayik görünümü ve böbreklerde büyüme gibi zehirlenme belirtilerine sebep olur. Toksin hayvanlarda gelişme hızında yavaşlama, safra kesesinde büyüme, lenfoid dokuda küçülme ve karaciğerde sentrilobuler nekroza da yol açar $(7,23,40)$.

\section{Patulin}

Patulin, A. clavatus ve $P$. patulum başta olmak üzere, tabiatta yaygin şekilde bulunan 50'ye yakın mantar türü veya suşu tarafindan hazurlanan bir mikotoksindir. Hayvanlarda patulinin $\mathrm{OD}_{50}$ değeri 10 $35 \mathrm{mg} / \mathrm{kg}$ arasında değişir. Patulin hayvanlarda öncelikle beyin kanaması vc ödemine, sinirsel belirtiler, dalak, böbrek ve karaciğerde kapillar damar hasarına ve ölüme yol açar. Keza, kemirici hayvanlarda DA yolla bir kaç kez uygulanması halinde, deri kanserine sebep olduğu belirlenmiştir $(7,46)$.

\section{Slaframin}

Bu madde Rhizoctonia leguminicola tarafindan hazırlanan, piperidin türevi parasempatomimetik etkili bir mikotoksindir. Hayvanlar tarafından alındıktan sonra 10-40 dk içinde tükrük, mide ve pankreas salgısında artışa, kalp hızında yavaşlamaya, vücut ısısı, süt verimi, metabolik hız ve kalp debisinde düşmeye, mide şişkinliği, sık sık işeme ve sürgüne, uterus kanaması ve yavru atmaya scbep olur. Toksin aslinda ön bir maddedir; $M E$ aracilyğnda etkin bir metaboliti olan ketoimine çevrilir. Toksinin etkileri atropin ve antihistaminiklerle önlenebilir; dolayısiyle, zehirlenmelerde bu maddeler yararlı olmaktadır (43)

\section{Sonuc}

Cllkemizde bir yandan tarımsal üretim tckniklerinin iyi gelişmemiş olması ve mevcutların da yeterince etkin biçimde kullanılamaması, diğer taraftan tarımsal üretimi artırmak amaciyla, tohum atma veya 
dikme zamanından başlayarak, ürünün hasadı-depolanmasına kadar her aşamada koruyucı ve verim artırıcı amaçlarla çok sayıda kimyasal maddenin (insektisidler, herbisidler, fungisidler, gelişmcyi hızlandırıcı ve düzenleyici maddeler gibi) kullanılması tarımsal ürünler ve dolayısiyle yem ve yem hammaddelerinde hayvanlar için çok sayıda olumsuzluk faktörünün bulunmasını kaçınılmaz yapabilmektedir. Bu maddelcrden bazıları yem veya yem hammaddesinin üretimi-hazırlanması sırasında ortamdan etkin biçimde uzaklaştırılabilmekte; bazıları ürctim-hazırlama işlemleri sırasında uygulanan fiziksel ve kimyasal maddelerle hayvanlar için zararsız düzeylere kadar azaltılabilmekte; bazıları tarımsal ürünlcrin harmanlanması, taşınması ve depolanması sırasında alınan bazı tcdbirlerle önemli ölçüde sınırlandırılabilmekte ve bazıları da canlının vücudunda çeşitli biyotransformasyon tepkimeleri ile zararsız metabolitlere çevrilebilmektedir. Ancak, yapılacak her türlü koruyucu uygulamaya rağmen, yem ve yem hammaddelerinde hayvanların sağlığını ve verimini olumsuz yönde etkileyecek faktörlerden kaçınılmayacağı da bir gerçektir.

\section{Kaynaklar}

1. Allcroft, R. and Rokerts, B.A. (1968). Toxic groundnut meal :the relationship between of aflatoxin $B_{1}$ intake by cows and excretion of aflatoxin $M_{1}$ in milk. Vet. Rec. 82:116-118.

2. Anon. (1979). Prevention of mycotoxins. Food and agricultural organization of the UN. Rome.

3. Anon (1980). Mycotoxins. Environmental health criteria 11. WHO. Geneva.

4. Anon. (1991). Tarım, Orman ve Köyişleri Bakanlığı, Koruma ve Kontrol Genel Müdürlüğü tebliği. 20.9. 1991 tarih ve 20997 sayılı Resmi Gazete.

5. Bagley, C.V. and Shupe, J.L. (1986). Sporidesmins facial eczema and pithomycosis. p. 375-386. Ed. J.L. Howard. In: "Current veterinary therapy. Food animal practice 2". W.B. Sounders Company.

6. Berardi, L.C. and Goldblatt, L.A. (1969). Gossypol. In Toxic constitutients of plant foodstuffs. (Liener, 1.E., Ed.,). pp. 212-266.

7. Betina, V. (1989). Mycotoxins : chemical, biological and environmental aspects. Elsevier. Amsterdam. 
8. Roland, R.L. (1986). Plants as sources of vitamin $D$ metabolites. Nutr. Rev., 44:I-8.

9. Bondi, A. and Alumot, R. (1987). Anti-nutritive factors in animal feed stuffs and their effects on livestock. Progress in Food and Nutrition Science, 11: 115-151.

10. Brown, J.F. (1977). Regulatory consideration of aflatoxin in regard to animal feed safety. Proceeding of the annual meeting of the US animal health associacions. 81: 211-214.

11. Cheeke, P.R. (1976). Nutritional and physiological properties of saponins. Nutr. Rep. Intern., 13:315-324.

12. Clarke, J.M.L., Harvey, D.G. and Humphreys, D.J. (1981). Veterinary toxicology. Second edition. Bailliere Tindall. London.

13. Conn, E.E. (1973). Cyanogenetic glycosides. p. 299-309. In: "Toxicants occuring naturally in foods" National Academy of Sciences. Washington, D.C.

14. Davies, N.T. (1979). Anti-nutritive factors affecting mineral utulization. Proc. Nutr. Soc., 38: 121-128.

15. Gallagher, C.H., Koch, J.H., Moore, R.M. and Steel, J.D. (1969). Toxicity of Phalaris tuberosa for sheep. Nature (London), 204:542-545

16. Foster, T.S. (1974). Physiological and biological effects of pesticide residues in poultry. Residue Rev., 51: 69-122.

17. Hatch, R.C. (1988). Poisons causing respiratory insufficiency. p. 1001-1131. In: "Veterinary Pharmacology and Therapeutics". Eds. N.H. Booth and L.E. McDonald. Sixth ed., Iowa State Liniversity Press. Ames.

18. Huff, W.E. Kubena, L.F. and Harvey, R.B. (1988). Toxic synergism between aflatoxin and T-2 tnxin in broiler chickens. Poultry Sci., 672-1418-1423.

19. Humpreys, D.J. (1979). Poisoning in poultry worlds. Poultry Sci., $35: 161-176$.

20. Ishaaya, I., Birk, Y., Bondi, A. and Tencer, Y. (1971). Soybean saponins. IX Studues of their effect on birds, mammals and cold-blooded animals. J. Sci. Food Agric., 20:433-436.

21. Jordan, F.T. Howell, J.M., Howarth, J. and Rayton, J.K. (1971). Clinical and pathological observations on field and experimental zoalene poisoning in broiler chicks and laying hens. Avian Path., 5: 175-178. 
22. Kakede, M.L., Simons, N.R., Liener, I.E. and Lambert, J.W. (1972). Biochemical and nutritional assessment of different varieties of soybeans. J. Agric. Food Chem., 20:87-90.

23. Kaya, S. (1989). Yem ve besinlerdeki mikotoksinler: Insan ve hayvan sağlı̆̆ı için önlemleri. A.Ü. Vet. Fak. Derg., 36:226-253.

24. Klaui, H. (1979). Inactivation of vitamins. Proc. Nutr. Soc., 38:138141 .

25. Kumar, R. and Singh, M. (1984). Tannins: their adverse role in ruminant nutrition. J. Agric. Food. Chem., 32:447-153.

26. Linear, I.E. (1969). Miscellaneous toxic factors. p. 410-448. In: Toxic constituents of plant foodstuffs. Academic Press. New York.

27. Linear, I.E. (1976). Phytohemogglutinins. Ann. Rev. Plant Physiol., 27:291-319.

28. Liener, I.E. (1979). The nutritive significance of plant proteas inhibitorr. Proc. Nudr. Soc., 38: 109-113.

29. Linagan, G.W. and Smith, L.W. (1970). Metabolism of pyrrolizidine alkaloids in the ovine rumen. Austr. J. Agr. Res., 21:493-500.

30. Livingstone, A.L. (1978). Forage plant estrogens. J. Toxicol. Environ: Health. 4: 301-310.

31. Lloyd, W.E. (1986). Urea and other nonprotein nitrogen sourges. p. 354-356. In: "Current veterinary therapy. Food animal practeic 2" Ed. J.L. Hovard. Sounders Company.

32. Mhittemore, C.T., Moffat, J.W. and Thylor, A.G. (1975). Influence of cooking upon the nutritive value of potato and maize in diets for growing pigs. J. Sci. Fd. Agric., 26: 1567-1576.

33. Mitaru, B.N., Reichert, R.D. and Blair, R. (1983). Improvement of the nutritive value of high tannin sorghum for broiler chicks by high mousture storage (reconstitution). Poultry Sci., 62:2065-2072.

34. Montgomery, R.D. (1969). Cyanogens. p. 143-157. In: "Toxic constituents of plant foodstuffs". Ed. I.E. Liener. Academic Press. New York.

35. Nowberue, P.M. (1974). The new world mycotoxins-animals and human health. Clinical Toxicol., 7:161-177.

36. Osweiller, G.D. (1986). Ergat (gangrenous). p. 367-369. In: "Current veterinary therapy. Food animal practice 2". Ed. J.L. Howard. W.B. Saunders Company.

37. Palmer, M.H., Britton, W.M. and Howarth, B. (1971). Influence of high DDT levels in the diet of laying hens on fertility. hatchability and chick mortality. Poult. Sci., 50:1615-1515. 
38. Quian, S.Z. and Wang, Z.G. (1984). A potential antifertility agent for males. Ann. Rev. Pharmacol. Toxicol., 24:329-368.

39. Radostits, 0.M., Searcy, G.P. and Mitchell, K.G. (1980). Moldy steete lover poisoning in cattle. Can. Vet. J., 21:155-160.

40. Scott, P.M. (1978). Mycotoxins in feeds and ingredients and their origin. J. Fd. Protec., 41:385-398.

41. Shull, L.R. and Cheeke, P.R. (1983). Effects of synthetic and natural toxicants on livestock. J. Anim. Sci., Suppl., 2, 57:330-354.

42. Singleton, V.L. and Kratzer, F.H. (1973). Plant phenolics. p. 309-340. In: "Toxicants occurring uatcrally in focds". National Academy of Sciences. Washington. D.C.

43. Smalley, E B. and Sanderson, J.M. (1986). Slaframine (slobber factor). p. 373-375. In: "Current veterinary therapy. Food animal practice 2". Ed., J.L. Hovard. W.B. Sounders Company.

44. Şanl, Y. (1980). Besinlerde küflenme clgusu te mikotoksinler. Gida Bilim ve Tek. Derg., ?:127-117.

45. Şanl, Y. ve Kaya, S. (1991). Veteriner Farmakoloji ve İlaçla Sağı̆ıtım Seçenekleri. Medisan yayınlar!. Ankara.

46. Sanl,, Y. ve Kaya, S. (1992). Veteriner Klinik Toksikoloji. Medisan yayınları. Ankara.

47. Şanl, Y. ve Kaya S. (1993). Veteriner Ilaç Rehberi ve Uygulamalı Bilgiler El Kitabı. Medisan yayınları. Ankara.

48. Turner, C.A. and Kienholz, E.W. (1972). Nitrate toxicity. Feedstuffs. $27: 28-31$.

49. Von Egmond, H.P. (1989). Current situation on regulation for mycotoxins. Overview of tolerance and status of standard methods of sampling and analysis. Food Additives and contaminants. 6:139-188.

50. Way, J.L. (1984). Cyanide intoxication and its mechanism of antagonism. Ann. Rev. Tharmacol. Toxicol., 24:451-481.

51. Whitaker, J.R. and Feeney, R.E. (1973). Enzyme inhibitors in foods. p. 276-299. In: "Toxicants occuring naturally in foods" National Academy of Sciences. Washington, D.C.

52. Willet, L.B. and Hess, J.F. (1975). Polychlorinated biphenyl residues in silos. Residue Rev., 55:135-145.

53. Wilson, B.J. (1980). Hazards of mycotoxins in public health. Fed. Prof. $41: 375-384$. 